\title{
Implementation of Extramural Learning Mode within the Gulf Region: An Analytical Study for Dhofar University
}

\author{
Amal Al-Dujaily, M.J Al-Fallogi \\ Dhofar University, Oman \\ amal_aldujaily,mfalloogi\{@du.edu.om\}
}

\begin{abstract}
This study explores the possibility of employing the extramural study method within the Gulf region. As a case study, Dhofar University (DU) has been selected given that it is the oldest private university situated in Dhofar region of the Sultanate of Oman. The authors have observed an increasing interest in the extramural method of study, especially for theory based courses. A survey was conducted at DU covering a sample size of 225 participants: 210 of which were tertiary students and 15 faculty members. Consequently, the survey results indicate that many DU students wish to obtain degrees externally, whether fully or partially, through extramural method of study. Female students, in particular, seek to continue their studies extramurally due to some affecting cultural factors, such as traditions and family commitments. Other factors such as study costs, employment, social status, living conditions and transportation have created obstacles to women in pursuing higher education. By aligning students' and lecturers' recommendations from this survey, we conclude that some changes in course delivery need to be made in order to create more learning opportunities for all students. This teaching system requires a more elastic, but realistic, approach with the option of theory based extramural courses. The implementation of such a teaching method would provide educational flexibility as well as financial benefits to the university and the larger Dhofar region.
\end{abstract}

\section{Introduction}

Studying via distant education (extramurally) has increasingly become a popular studying method among the Omani students as for the rest of the world [1, 2, 3]. Over the past 5 years, several thousands of Omani students have joined universities in the neighboring countries that offer qualification degrees via distant learning [4].

Dhofar University has both the potential and the need to commence a distant learning study program. Given that D.U. has the advantage of leading Oman's private institutes of higher education for being an older organization with records of academic excellence that has an international reputation for quality research. In addition, as a private university, D.U. is not restricted to adopting a full-time study method as for the Omani public universities. The nature and location of the Dhofar region on the Great Arabian Desert border, $1100 \mathrm{~km}$ from the capital Muscat, increases the need for an extramural study program which could bring about benefits for the students, the university and the entire region.

In accordance with the factors that have generated the need for the extramural study method for Oman's students, the recommended option is the combined use of CD-ROM [7] and IDL (Integrated Distance Learning) system [8]. This recommendation is based on the fact that the delivery of the courses and testing materials by this recommended system is fairly straightforward, which in turn ensures its availability to the students upon their at most convenience. However, several problems may arise when the students are required to complete assignments, quizzes or exams. In this case, students will need to physically attend at least once by the end of each semester.

\section{Background}

Distant education is not a new method of learning. It has been used for more than a century. The University of London was the first university to offer distant learning degrees, in 1858 [2]. The first correspondence school in the United State was founded in Boston by Anna Eliot Ticknor in 1873. In Australia, the University of Queensland established its Department of Correspondence Studies in 1911 [5]. Another pioneering institution was the University of South Africa, which has been offering Correspondence Education courses since 1946. In New Zealand, university-level distant education or extramural study began in 1960 at Massey University. The largest distant education program in the United Kingdom is the Open University, which was founded 1969. In Germany the FernUniversität in Hagen was founded 1974. In 2006 the Sloan Consortium reported that more than 96 percent 
of the largest colleges and universities in the United States offered online courses and that almost 3.2 million American students were taking at least one online course during the fall 2005 term [6].

As a part of distant learning, extramural study focuses on pedagogy (strategies of instruction), technology, and instructional [1] systems designs that deliver education to students not by physical means "on site". Instead of attending courses in person, teachers and students may communicate throughout the use of printed or electronic media, or through technology that allows them to communicate in real time and via other online methods. Distant education courses requiring some on-site attendance are considered a 'hybrid' or 'blended' courses of study. There are a number of ways to choose from when considering an extramural method of delivering courses, choosing which depends on the best fit for the teaching environment of the university.

\section{Research Method and Questions}

The research was carried out using the survey method which was conducted with students and faculty members of D.U. The two major survey questions used for the students: "Are Omanis students familiar with extramural method of study at the Tertiary level? If YES, would they prefer this option over the current method; and, if so why?”

The academic staffs were also asked: to what extent do they support the extramural study method for DU students?

\subsection{Participants}

A stratified random sample proportional to the size was taken from both students and members of staff at Dhofar University. A total of 108 male and 102 female students representing $5 \%$ of the total enrollment were selected randomly from the most popular departments of Commerce and Business Administration Collage within the university, taking into account the size of each selected department. The faculty sample of 15 university lecturers was selected on the same basis

\subsection{Survey Findings}

\section{Part I: Students}

1. Almost $50 \%$ of Omani students had no idea about extramural method of learning and were only familiar with the traditional methods offered at their local institutes of higher education. While nearly 53\% of male students had previous knowledge of the existence of this method, only $46 \%$ of females were familiar with the extramural study method. This result may be due to lack of educational marketing for this type or study within the Gulf region.

2. Working students are relatively more familiar with extramural study method than the non-working students: Working females are very small in proportion to male working students and yet students' employment is generally not so common in the Gulf region.

3. Omani females prefer extramural methods of learning relative to males at $\mathrm{p}<.05$; the female preference ratio is $63.7 \%$ compared with $54.5 \%$ for male. Younger females in particular prefer more of the learning style of extra mural $71.2 \%$ comparing with $31.6 \%$ for younger male. Such results are of course surprising; nevertheless, it shows how important studying from home is to young women affected by culture and other factors like family traditions.

4. There is an overall age-group effect on students' preferences such that older students prefer extramural more than younger students at $\mathrm{p}<.05$. This is a prepredictable result since most of the older generation students are either engaged in employment, family concerns or both and thus have less time devoted to traditional ways of learning . Also, $90.5 \%$ of employed students prefer extramural learning method compared to $51.2 \%$ of unemployed students. The p-value is significant at $\mathrm{p}<.01$, indicating a highly significant employment effect on student's preferences. Similarly, students preferences are highly affected by social status $\mathrm{p}<.01$. Almost $91 \%$ of married students prefer extramural study compared with $53.4 \%$ of unmarried students.

5. There is a significant location effect of $\mathrm{p}<.05$. Regardless of gender or age group, most students living in rural area prefer extramural study compared with students living in urban areas. This indicates that students' location has a considerable effect on the students' presence of learning methods. Students living far away from educational institutes prefer more comfortable way of learning such as distant learning or extramural. Moreover, students paying their university fees prefer to study in cheaper way like extramural very unlikely to those having full or partial grants. $91.4 \%$ of self supported students prefer extramural comparing to $19.1 \%$ of students with government or companies grants.

6. Students' preferences towards extramural study depend on their specialization and the subject's materials that they are studying. Table 1 show that students in certain departments such as Marketing, Business and Finance are supporting the extramural method relatively more than those students studying in MIS or Accounting departments. However, student's preference varies from $50 \%$ in the Finance department to almost $90 \%$ in the Business department. These specializations, of course, 
need relatively less face to face interaction between students and instructors than Accounting and MIS need.

Table 1. Preference of Extramural by Departments

\begin{tabular}{|l|c|c|c|c|c|}
\hline $\begin{array}{l}\text { Preference/ } \\
\text { Department }\end{array}$ & Yes & $\%$ & No & $\%$ & Total \\
\hline Marketing & 34 & 81.0 & 8 & 19 & 42 \\
\hline Business & 41 & 89.1 & 5 & 10.9 & 46 \\
\hline MIS & 33 & 39.3 & 51 & 60.7 & 84 \\
\hline Finance & 8 & 50 & 8 & 50 & 16 \\
\hline Accounting & 8 & 36.4 & 14 & 63.6 & 22 \\
\hline Total & 124 & & 86 & & 210 \\
\hline
\end{tabular}

\section{Part II: Faculty Members}

Regardless of gender younger staff are less familiar with extramural than older ones, $33.3 \%$ compared to $66.7 \%$, reflecting significant differences $(\mathrm{p}<.05)$ in extramural familiarity related to faculty members' age. The faculty members' support of extramural study is strongly dependent on their field of specialization. The results show that $100 \%$ of tutor in marketing department are proextramural.

\section{Conclusions}

Gulf students, and more specially Omani, are in some way familiar with the extramural method of study; many of them have experienced this method in high schools, particularly in the pre-university level. However, this facility is not available in Oman at university level; consequently, some irregular attendees join universities which offer some degrees via the extramural method, mainly in Yemen, Lebanon or in Egypt.

From this survey, we have observed a strong demand for the extramural study, at least for some courses. The majority of Dhofar university's students, predominantly females wish to obtain their qualifications externally either fully or partially by the extramural method. Multiple reasons were given with this regard but we found that cultural restrictions, family traditions and family commitments were among the most important ones. Other reasons such as: the costs of studying, employment, social status, living status and transportation were also among the important ones but were given second priority.

The lecturers whom participated in this survey agreed upon the need for having an elastic but realistic method that allows for some courses to be covered by extramural. Lecturers were a bit conservative about the idea of having a full on extramural option of study as they have their doubts about the students' self-reliance standards Moreover, distance education has long had trouble with testing. The delivery of testing materials is fairly straightforward so that they are available to students who can read it at their leisure. The problem may arise when student is required to complete assignments and tests. Online courses have had difficulty controlling cheating in quizzes, tests, or examinations because of the lack of teacher control. Some schools address integrity issues concerning testing by requiring students to take examinations in a controlled setting. A minor number of lecturers also fear that greater work commitments would be needed when combining extramural along with the traditional method of teaching.

\section{Recommendations}

It is vitally important for the Gulf region to have at least one university offering some degrees via extramural studies given that students' circumstances may vary; nonetheless, they should all have the opportunity to continue their studies in spites of their differences. Not all students are able to attend classes on regular basis. Also, not all the students can afford to pay a full fee. Extramural method is suitable not only for female students but also for those living in rural areas that struggle from consistent hardship, it is ideal for both male and female students with family commitments.

On the other hand, the increasing utilization of extramural technology in educational institution around the world has made it necessary to consider the possibilities of implementing the extramural approach in Dhofar University in order to compete with other international universities that offer on-line degree and diploma courses. Economically, it has a great value of keeping the funds within Oman rather than spending it abroad. However, the disadvantages of the extramural study can be reduced by creating a more developed program that helps enhance students' learning performance and their consistent evaluations. Cheating can also be reduced by adopting a variety of methods to discourage cheating as well as increasing the number of quizzes, but the safest way at the mean time is to have the students complete the main examination in a controlled examination venue at the end of each semester.

Moreover, extramural learning method can be delivered in two ways: synchronous and asynchronous. Synchronous learning method refers to a real time interaction between the student and the instructor, which is usually facilitated by various means of media such as video-conferencing or live chat. While, asynchronous method of learning is more flexible and allows students to complete their studies at their own convenience. This is commonly supported by other forms of media such as emails, discussion boards, AudioGraph recorded lectures and video-text tutorials to help students understand how to use the technology. Yet, most instructors do not seem to prefer synchronous learning as they consider it unmanageable, especially for large groups of learners [9]. 
Other studies, such as Rossma, [10] and Matheson [11] have showed that learners prefer to take asynchronous courses in order to combine education with work, family, and other obligations. In addition, asynchronous is recommended for group discussions, problem-solving and information sharing. Nevertheless an asynchronous course is favored by both instructors and students, some students might lose motivation and interest if they lose physical touch with their instructors and ultimately find that learning and retaining the material is boring and nearly impossible [12].

Having all the previously mentioned points in mind, it is highly recommend implementing the asynchronous learning style for extramural method of learning in the Gulf region. Taking to account the advantages of this method being reliable, more flexible and permits students to complete their studies upon their convenience. Thus it is more suitable for university students in Gulf region.

Further study on this topic is underway.

\section{References}

[1] Holmberg, B. (2005). The evolutions, principles and practices of distance education. Bibliotheks-und Information system der Universitat Oldenburg. p. 13.

[2] "Key Facts", University of London External Programme Website, http://www.londonexternal.ac.uk/about_us/facts.shtml

[3] Moore, Michael G.; Greg Kearsley (2005). Distance Education: A Systems View, Second, Belmont, CA:Wadsworth.

[4] Arab University of Beirut.

[5] White, M. (1982). 'Distance education in Australian higher education a history', Distance Education, Vol. 3, pp. 255-278.

[5] Daniel, J.S. (1996). Mega-Universities and Knowledge Media: Technology Strategies for Higher Education, Kogan Page, London. isbn 0-7494-2119-3.

[6] Making the Grade: Online Education in the United States, 2006, The Sloan Consortium, http://www.sloanc.org/publications/survey/survey06.asp

[7] Taylor, J.C. 2003, 'The Fifth Generation of Distance Education', Translation in the Chinese Journal of Open Education Research, 3, 25 - 27, June

[8] GHP, MBA Trends: Integrated Distance Learning, Retrieved August 6, 2008

[9] Wang, A. \& Newlin, M. (2005). Technical horizons in education: Promoting Synchronous Interaction in an eLearning Environment: The journal.http://thejournal.com/ articles/2005/09/01/promoting-synchronous-interaction-in-anelearning-nvironment.aspx. (Access date: 10 December, 2009).
[10] Mark H. Rossman, Ed.D, (2009, November) Successful online teaching using an asynchronous learner discussion forum: The Sloan Consortium, 3, 2.http://www.aln.org/ publications/jaln/v3n2/v3n2_rossman.asp. (Access date: 9 December, 2009).

[11] Matheson, J. (2006, August). Asynchronous and synchronous communication and activities in online education. http://e-articles.info/e/a/title/Asynchronous-and-SynchronousCommunication-and-Activities-in-Online-Education/. （Access date: 10 December, 2009).

[12] Ballou, J. (2009, January). Asynchronous Learning Advantages and Disadvantages: Ballou Blog. http://jamesballou.com/Tabula/?p=32. (Access date: 2 December, 2009). 